nations not merely for the operation of the machines which exist at present but also, with luck, for the building of the $300 \mathrm{GeV}$ accelerator as well.

But is there time to think of negotiating such a complicated arrangement at this late stage? This is what the enthusiasts will say. The truth is, however, that ever since the publication of the Swann report which formed the basis for the British Government's decision not to participate in the $300 \mathrm{GeV}$ project, it has been clear that the continued financing of high energy physics could not be accommodated within the ordinary framework of support for basic scientific research. In Britain, the fear is that high energy physies can only continue to exist at the expense of other more worthwhile activities. Elsewhcre the sheer cost of what is now proposed seems to be a sufficient disincentive, while other nations in Europe are understandably disinclined to participate either because they have recently acquired reasonable facilities of their own or because they attach low priority to the work proposed.

There is no cause for the high energy physicists to complain about this state of affairs-instead, they must learn to live with it. On the long view, the $300 \mathrm{GeV}$ machine would be an asset to European science but it would be even more valuable if it could be built within a framework giving expression to the belief that physicists in particular are fond of quoting that branches of physics like these are already thoroughly international.

\section{Warm and Cheerful}

'IHE British Government has put itself into an awkward box on fuel policy and there is no assurance that the Conservative Cabinet will be any better than its Labour predecessor in finding a way out. A part of the difficulty seems to be that of forecasting the demand for energy a fow years ahead. By now, the record of failure in this field is as long as any arm. In the mid-fifties, people were anxious that Britain would be brought suddenly to a halt by a lack of fuel, and miners were exhorted to dig more coal. Then, in 1955, the government pinned its colours to the mast of nuclear power, and miners were exhorted to find jobs outside the coalfields. Since then, the prevailing view has swung radically between the promise of shortage of coal and the threat of glut. The most recent development in Britain is that a shortfall in the output of nuclear power from nuclear fuelled power stations has been aggravated by a decision some years ago that there should be a reduction in the rate of capital investment in electricity generating plant and by a wastage of miners from the coalfields at such a rate that the miners now think themselves in a position in which they can successfully launch the first substantial strike since 1926 .

The fluctuations in the available supply of energy which seem to create difficulties are, it must be remembered, exceedingly small. The fuel economy is still so precariously balanced that a few million tons of coal either way, or the delay in the commissioning of a single nuclear power station, can tip the balance substantially towards surplus or shortage. Governments have a natural tendency to hope to manage their affairs with such precision that failures of this magnitude are rare or even non-existent but that is a great conceit-prudent management would suggest that fluctuations of a few per cent, equivalent to ten million tons of coal a year, in the fuel budget ought to be expected. In short, if the new government is anxious to devise a fuel policy to replace that of its predecessor, it ought to legislate for some system under which the substitution of one fucl for another is comparatively straightforward.

What should this device be? For the best part of a decade, the British Government has done its best to make sure that the Central Electricity Generating Board will be discouraged from replacing indigenous coal by imported oil by means of a levy on fuel oil imported into Britain. This tax of ten per cent has been sufficient not merely to reduce the volume of oil imports but, alas, also to persuade the electricity generating board that taking out an option to burn fuel oil in British power stations would be an expensive luxury. By the same test, the electricity generating board has been discouraged from providing the excess capacity necessary to insure against unexpected developments. It is, however, idealistic to expect that newly commissioned innovations such as nuclear power stations will function perfectly in the first year of their service, and it is wrong to suppose that there is something wrong with the process of innovation if these devices fail to work perfectly the first time round. The moral should be, on the practical level, that the time has come to abolish artificial restraints on the British fuel economy and, in particular, that restraint on the use of fuel oil embodied in the present tax. In the long run, however, the British Government must sanction at least enough capital expenditure to ensure that there is enough give and take in the fuel economy for the most advantageous mixture of fuel to be that chosen by the market. It will be a lesson to us all to see whether a government which has flaunted its respect for market forces in the past few weeks is prepared to let these market considerations be acted out when a little extra capital investment may thereby be necessary.

\section{Telling If like If Is}

ONE of the problems of contemporary biography is that it is bound to read a little like obituary. Certainly the article on Dr Francis Crick in the current issue of Daedalus $(\mathbf{9 9}, 938)$ by Dr Robert Olby is not merely an intriguing preview of the full length manuscript on which Dr Olby has been working for several years but also a device that almost succeeds in fixing Crick in amber, or at least in aspic. What Dr Olby and the 